\title{
Maintenance and repair of steel reinforced concrete structures by galvanic corrosion protection - field experiences over 10 years
}

\author{
Wolfgang Schwarz ${ }^{1}$, Alexander Pichlhöfer ${ }^{1}$, Anthony van den Hondel ${ }^{2 *}$ and Hernani Esteves $^{3}$ \\ ${ }^{1}$ CAS Composite Anode Systems GmbH, 1080 Vienna, Austria \\ ${ }^{2}$ Cathodic Protection Supplies, 2908 KC Capelle aan den IJssel, Netherlands \\ ${ }_{3}^{3}$ iCOR GmbH, 41199 Mönchengladbach, Germany
}

\begin{abstract}
A galvanic zinc anode system, composed of a zinc mesh embedded into a proprietary solid matrix with ion exchange properties, was developed by CAS. The solid matrix of the embedded zinc anode system (EZA) is based on a tecto-alumosilicate-binder containing additives that prevent passivation of the zinc anode, assure high and durable galvanic activity of the zinc anode and high and durable adhesion towards the concrete overlay. The efficiency of the EZA, applied to concrete members of four types of civil structures - abutment of a road bridge in the Styrian Alps in Austria (2007), support-beams for the bearings of four viaducts in Den Hague in the Netherlands (2009) and a parking deck in Saas Fee in Switzerland (2011), was monitored with embedded reference cells and macro cell sensors. Data collected over a period of up to 10 years show that the EZA protects the steel reinforcement efficiently and reliably. An advanced EZA system - based on the novel shrinkage controlled EZA binder (SEZAC) - covered with a novel water vapor permeable epoxy/PU membrane was installed July 2017 at the tunnel entrance of a federal road in the Styrian Alps. The EZA exposed to harsh weathering conditions proves to be efficient in protecting the steel reinforcement from corrosion.
\end{abstract}

\section{Introduction}

Galvanic corrosion protection of steel in concrete is based on the formation of a galvanic element if a metal less noble than cast iron steel, in direct contact with the concrete overlay, is electrically connected to the steel rebars. The reinforcing steel is protected from corrosion as long as sufficient galvanic current flows between the galvanic anode and the steel reinforcement. Most commonly, zinc is used as the sacrificial anode material. The galvanic element formed corresponds to a conventional zinc/air battery that is becoming popular again as an alternative source of energy.

Galvanic corrosion protection was first employed to protect a bridge deck in Illinois in 1977 within the cooperative highway research program, with mixed results [1]. A problem with the initially applied sacrificial anodes was that their protection current decreases with time, and they eventually become passive, so most systems had a relatively short useful life [2]. In the 1990's, sacrificial anode systems based on sprayed zinc anodes, zinc foil glued to the concrete surface (zinc hydrogel system), zinc mesh pile jackets around bridge columns filled with sea water were starting to be evaluated and used for the protection of bridge structures [3-5]. To a limited extent, zinc anodes embedded into the concrete overlay, are used to protect the steel reinforcement especially accompanying concrete repair. The efficiency of galvanic corrosion protection depends on the lasting activity of the zinc anode. Deposition and agglomeration of the anodic products like zinc hydroxide and zinc hydroxychlorides or contact with calcium hydroxide in the pore solution may passivate the zinc anode surface. Service time of the zinc anode may be limited by self-corrosion that increases with the activation of the zinc anode and may reach up to $70 \%$ of the zinc consumed during operation. Sprayed zinc anodes require sufficient humidity and high chloride contents to operate satisfactorily [6]. Experience showed that most failures of galvanic systems occurred due to the failure of the adhesion of the anode to the concrete overlay and due to passivation of the anode exposed to frequent wet dry cycles or due to loss of alkalinity of the embedding mortar. Zinc-Hydrogel anodes are especially sensitive to exposure to high humidity with subsequent delamination. A novel galvanic zinc anode system, an embedded zinc anode (EZA), composed of a zinc mesh embedded into a proprietary binder that solidifies into a solid matrix based on a tecto-alumosilicate-binder containing additives that prevent passivation of the zinc anode, assure high and durable galvanic activity of the zinc anode and high and

\footnotetext{
* Corresponding author: hvdhondel@mourik.com
} 
durable adhesion towards the concrete overlay was applied first time in September 2007 at an alpine bridge in Austria and subsequently October 2009 at concrete beams supporting bridge decks in Den Haag in the Netherlands. The efficiency of the galvanic corrosion protection is monitored and evaluated on four types of civil structures a road bridge in the Styrian Alps (Austria (2007), supportbeams for the bearings of a road bridge in Den Hague (Netherlands 2008), parking deck in Saas Fee (Switzerland 2011) over a time period up to 10 years. A significantly improved EZA system, based on the SEZAC binder, was installed for demonstrative purposes at a tunnel entrance in Styria, Austria in summer 2017 - data are reported.

\section{Description of the System}

The galvanic EZA system is composed of a zinc mesh embedded into the proprietary solid electrolyte (figure 1). The EZA solid matrix is formed by the hardening of the shrinkage reduced embedding zinc activating cement (SEZAC). The SEZAC binder matrix function as a solid electrolyte, that ascertains an optimum electrolytic contact between the zinc anode and the concrete overlay, it prevents the self-passivation of the zinc anode and therefore assures an optimum and reliable protection of steel reinforcement endangered by, or already damaged by chloride induced corrosion. The EZA is placed on the surface of the concrete member in which the steel reinforcement is to be protected from corrosion: The concrete surface has to be prepared with the standard procedures for placing coatings on concrete surface (preferably grit blasting, high-pressure (400 bar) water jetting, etc.). Adhesion strength after 24 hours is in the range of $0.6-1.0 \mathrm{MPa}$, after 7 days $>2 \mathrm{MPa}$ and after 28 days about $2.5-3.0 \mathrm{MPa}$ at ambient temperatures of $20-$ $25^{\circ} \mathrm{C}$ and depending on substrate strength.

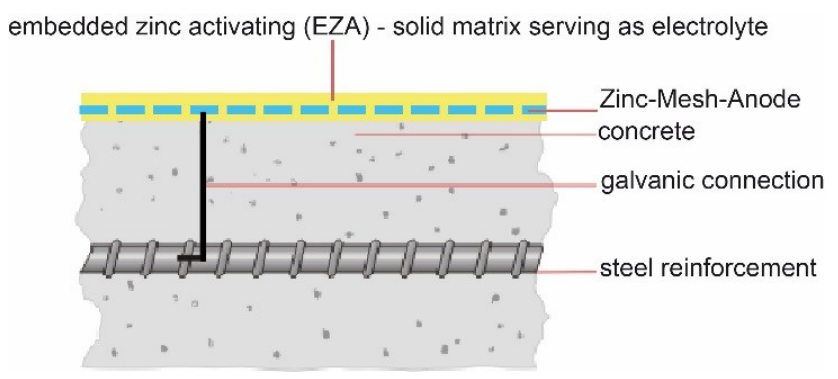

Figure 1. Embedded galvanic zinc anode (EZA): zinc mesh embedded into SEZAC binder forming the EZA-electrolyte

The efficiency of corrosion protection of the steel reinforcement by the EZA may be evaluated according to the procedure described in EN 12696 - the $24 \mathrm{~h}$ depolarization criterion and/or by macro cell current measurements [8]. To monitor the efficiency of the installed EZA systems, reference cells, macro-cell-, concrete resistivity, temperature and humidity sensors were installed and monitored with an automated monitoring system.

\section{Field Installations}

\subsection{Alpine Road Bridge}

For the evaluation of the efficiency and durability of the EZA system, a road bridge in an alpine region of Styria (Austria) was chosen (figure 2) for the following reasons: The bridge is located in the Styrian Alps in an altitude of $1000 \mathrm{~m}$ above sea level. The climate in that region is characterized by rapid wetting and drying cycles with large temperature differences in the summer including temperature changes crossing the thaw point and by frequent frost-thaw cycles with high exposure to de-icing salt during winter.

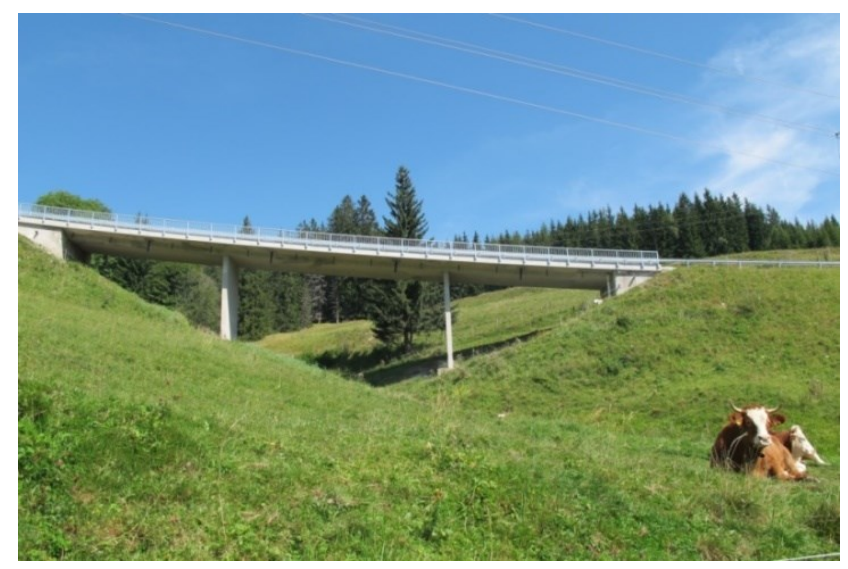

Figure 2. County road bridge "Alplgrabenbrücke" in the Styrian Alps on the county road B72.

\subsubsection{Description of Bridge Condition}

The bridge structure showed visible concrete damages cracks, spalling and corrosion - near the abutment "Birkfeld". Water and saltwater during wintertime penetrated the bridge deck through cracks due to the bridge deck bumping against the abutment. Chloride contents of $4.0-5.6$ wt. \% / cement weight down to a depth of $2 \mathrm{~cm}$ were measured in the areas that were frequently wetted. In the less frequently wetted areas, the chloride content was in the range from $0.5-0.9$ wt. \% / cement weight, carbonation depth was $\geq 4 \mathrm{~cm}$ at a concrete cover of $20-$ $40 \mathrm{~mm}$.

Therefore one has to assume high corrosion activity of the steel reinforcement of the concrete members with the risk of significant loss of cross section of the steel reinforcement in the future. 


\subsubsection{Installation of the EZA - System}

The EZA system for the galvanic corrosion protection (GCP) of the steel reinforcement in the concrete members of the county road bridge "Alplgrabenbrücke" was installed in September 2007. The EZA system was put into operation on 1 November 2007. Operational and performance data were presented at the ICCRRR [9].

The data proved that the steel reinforcement is reliably protected from corrosion by the EZA system. The owner of the bridge - the Styrian department of bridge construction and repair - decided during the general bridge repair, executed from 21 June until 21 August 2012, to take over the EZA on the abutment. To assure frost thaw salt resistance and to increase performance, especially with respect to the galvanic chloride extraction, the EZA was coated with an elastic acrylic coating. In an area of about one $\mathrm{m}^{2}$, the EZA was renewed by embedding a zinc mesh into the EZA binder on top of the existing EZA (figure 3).

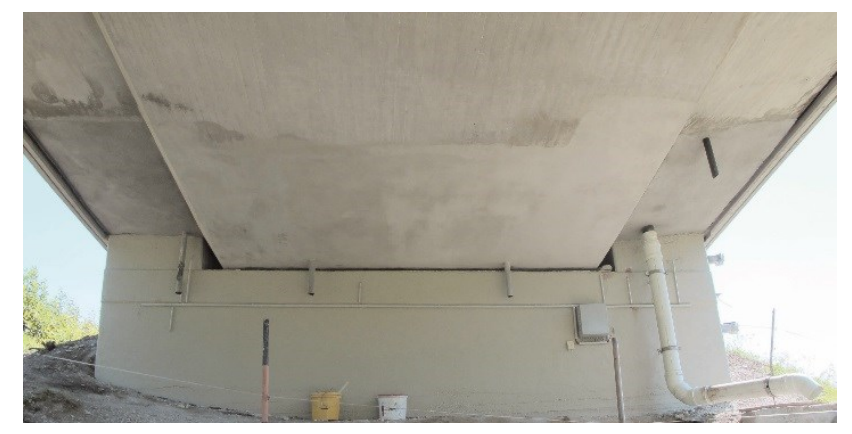

Figure 3. View on the EZA installed on the abutment of the Alplgrabenbridge

\subsubsection{Data of Operation of the EZA - system}

The operating data of the EZA-system over a period of 10 years (1 November 2007 - 1 November 2017) were evaluated and analysed with respect to stability, performance and durability. The galvanic system was put out of operation for about 2 weeks during bridge refurbishment in July 2012 and restarted again on 8 August 2012. Galvanic currents in relation to macro-cell currents measured by macro-cell sensors, installed to monitor protection efficiency and eventual corrosion currents, demonstrated that the steel reinforcement is fully protected (Figure 4). Temporary corrosion currents were only observed during the 24 hour depolarisation measurements.

The initially high galvanic current of the EZA-system decreased during the first three months continuously and stabilized after about 2 years. The galvanic current decreased at dry ambient air $(\mathrm{RH}<50 \%)$ and temperatures below freezing but increased immediately if humidity levels and/or temperature increased again to the values previously measured at the corresponding humidity and/or temperature levels. Furthermore, the numerous wet/dry and freeze/thaw cycles did not affect the long-term performance of the EZA-system. The galvanic zinc anode protects the steel reinforcement reliably and durable from corrosion. The efficiency of the corrosion protection of the GCP systems was verified by depolarization measurements according to EN 12696 [9-10]. The EZA system is fully functional after seven years of operation enduring seven alpine winters.

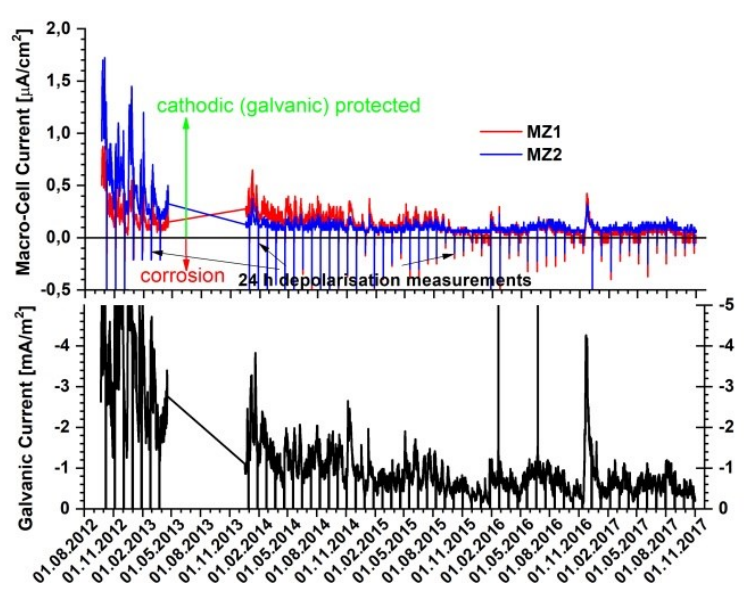

Figure 4. Galvanic Current of the EZA-System in relation to macro-cell currents measured by macro-cell sensors.

Drilled cores showed that in areas where the EZA was soaked with de-icing salt solution from the in-side through cracks across the bridge deck, the compound between the EZA mortar and the concrete remained fully intact. The galvanic corrosion protection was therefore guaranteed in all areas in which the EZA anode is installed. From the charge passed during the operation of the system and based on samples of the zinc mesh drawn from various areas, a service time of about 15 years is estimated.

\subsection{Hubertusviaduct' in The Hague}

This 2009 project in The Hague was initiated by the municipality. During damage assessment of a large flyover junction 'Hubertusviaduct,' with 4 abutment walls, there was a chloride induced reinforcement corrosion problem in the concrete just beneath the expansion joints. During the repair works, all expansion joints were replaced with new, water-tight rubber joints. The concrete damage was repaired and the abutment was cathodically protected. In total $90 \mathrm{~m}^{2}$ were covered with zinc mesh with a total of $2 \mathrm{~kg}$ per $\mathrm{m}^{2}$ of concrete (figure $5 \& 6$ ). Considering the low reinforcement density, a lifetime of over $10-15$ years is expected. A total area of $90 \mathrm{~m}^{2}$ of concrete was protected on 4 different locations, divided into 5 separate zones. Each zone was installed with a decay-probe (activated titanium $\mathrm{Ti}^{*}$ ) and a reference-electrode (ERE 20 $\mathrm{Mn} / \mathrm{MnO}_{2}$-type). All connections within a zone to the reinforcement, the zinc-anode, the decay-probe and the reference-electrode were made in a connection box. The 
entire surface was coated with the Decadex coating system.

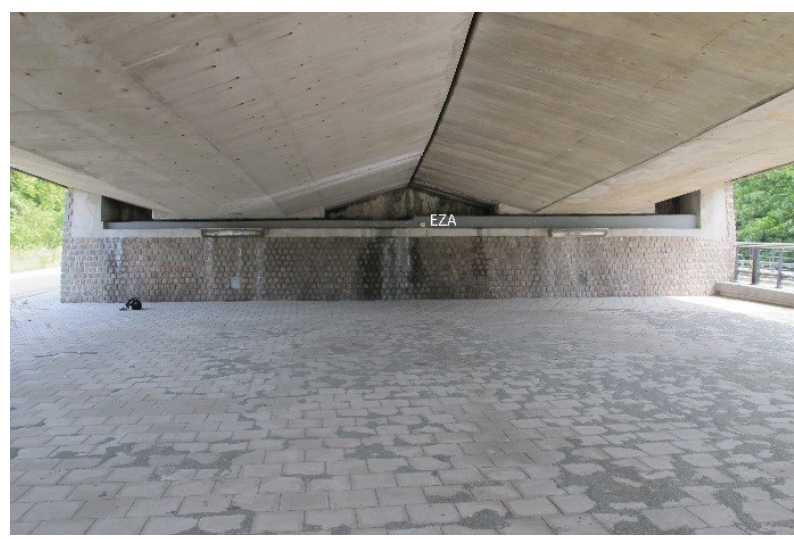

Figure 5. EZA installed on the beams supporting the bearings of the Hubertus viaduct.

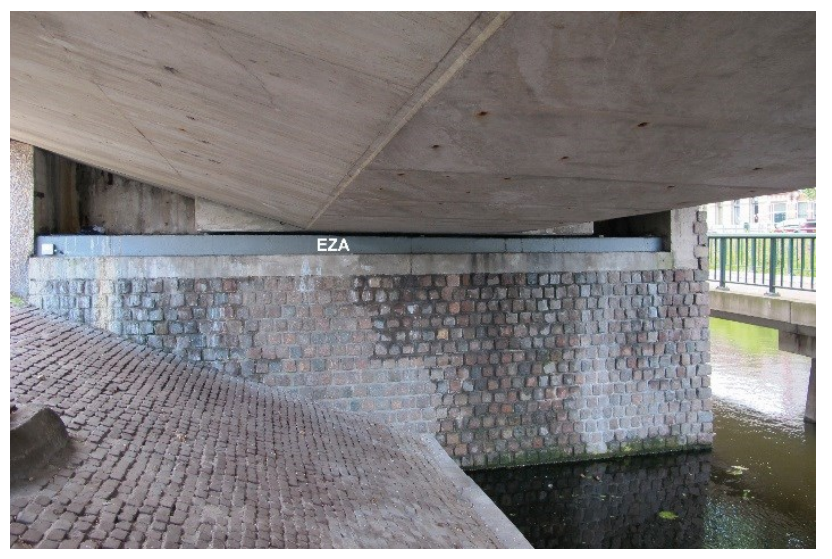

Figure 6. EZA installed on the beams supporting the bearings of the Hubertus viaduct.

Table 1. Verification of the effectiveness of the EZA by 24 $\mathrm{h}$ depolarization measurements according to ISO EN 12 696. Potential values in $\mathrm{mV}$, measured on beams shown in figure 5.

\begin{tabular}{|c|c|c|c|c|c|c|}
\hline Date & $\begin{array}{l}\text { Ref. } \\
\text { Cell }\end{array}$ & $\begin{array}{l}\text { On- } \\
\text { pot. }\end{array}$ & $\begin{array}{c}\text { Inst. } \\
\text { off }\end{array}$ & $\begin{array}{l}4 \mathrm{~h} \\
\text { off }\end{array}$ & $\begin{array}{c}24 \mathrm{~h} \\
\text { off }\end{array}$ & $\begin{array}{c}24 \mathrm{~h} \\
\text { Depol }\end{array}$ \\
\hline 30 & $\mathrm{MnO}_{2}$ & -547 & -457 & -386 & -288 & 169 \\
\hline $\begin{array}{l}\text { June } \\
2011\end{array}$ & $\mathrm{Ti}^{*}$ & -366 & -278 & -183 & -91 & 187 \\
\hline $\begin{array}{c}30 \\
\text { July }\end{array}$ & $\mathrm{MnO}_{2}$ & -551 & -499 & -404 & -245 & 254 \\
\hline 2013 & $\mathrm{Ti}^{*}$ & -356 & -314 & -237 & -70 & 244 \\
\hline 25 & $\mathrm{MnO}_{2}$ & -486 & -402 & -367 & -250 & 152 \\
\hline $\begin{array}{l}\text { Ivay } \\
2016\end{array}$ & $\mathrm{Ti}^{*}$ & -325 & -291 & -244 & -77 & 221 \\
\hline 24 & $\mathrm{MnO}_{2}$ & -552 & -512 & -417 & -234 & 278 \\
\hline $\begin{array}{c}\text { Mai } \\
2017\end{array}$ & $\mathrm{Ti}^{*}$ & -338 & -309 & -233 & -75 & 234 \\
\hline $\begin{array}{c}28 \\
\text { Nov. }\end{array}$ & $\mathrm{MnO}_{2}$ & -568 & -535 & -399 & -343 & 192 \\
\hline 2017 & $\mathrm{Ti}^{*}$ & -350 & -321 & -264 & -169 & 152 \\
\hline
\end{tabular}

Table 2. Verification of the effectiveness of the EZA by 24 $\mathrm{h}$ depolarisation measurements according to ISO EN 12 696. Potential values in $\mathrm{mV}$, measured on beams shown in figure 6.

\begin{tabular}{cllllll}
\hline Date & $\begin{array}{l}\text { Ref. } \\
\mathrm{Cell}\end{array}$ & $\begin{array}{l}\text { On- } \\
\text { pot. }\end{array}$ & $\begin{array}{l}\text { Inst. } \\
\text { off }\end{array}$ & $\begin{array}{l}4 \mathrm{~h} \\
\text { off }\end{array}$ & $\begin{array}{l}24 \mathrm{~h} \\
\text { off }\end{array}$ & $\begin{array}{l}24 \mathrm{~h} \\
\text { Depol. }\end{array}$ \\
\hline $\begin{array}{c}30 \\
\mathrm{July}\end{array}$ & $\mathrm{MnO}_{2}$ & -559 & -507 & -466 & -327 & 180 \\
2013 & $\mathrm{Ti}^{*}$ & -288 & -245 & -194 & -115 & 130 \\
\hline $\begin{array}{c}25 \\
\mathrm{May}\end{array}$ & $\mathrm{MnO}_{2}$ & -430 & -416 & -353 & -302 & 114 \\
2016 & $\mathrm{Ti}^{*}$ & -279 & -256 & -185 & -118 & 138 \\
\hline $\begin{array}{c}24 \\
\mathrm{Mai}\end{array}$ & $\mathrm{MnO}_{2}$ & -552 & -512 & -417 & -234 & 278 \\
2017 & $\mathrm{Ti}^{*}$ & -338 & -309 & -233 & -75 & 234 \\
\hline $\begin{array}{c}28 \\
\text { Nov. }\end{array}$ & $\mathrm{MnO}_{2}$ & -568 & -535 & -399 & -343 & -192 \\
2017 & $\mathrm{Ti}^{*}$ & -350 & -321 & -264 & -169 & -152 \\
\hline
\end{tabular}

The results show that over a period of more than 8 years, the $24 \mathrm{~h}$ depolarization values are fare above 100 $\mathrm{mV}$ required by ISO EN 12696 for reliable corrosion protection.

\subsection{Parking Deck in Saas Fee}

The parking garage in Saas Fee is designed to take in all cars of tourists and inhabitants of Saas Fee - the village of Saas Fee is free of fuel powered vehicles. The parking deck was erected 1979/80 and extended with a new section 1980/81, offering 2900 parking lots (figure 7).

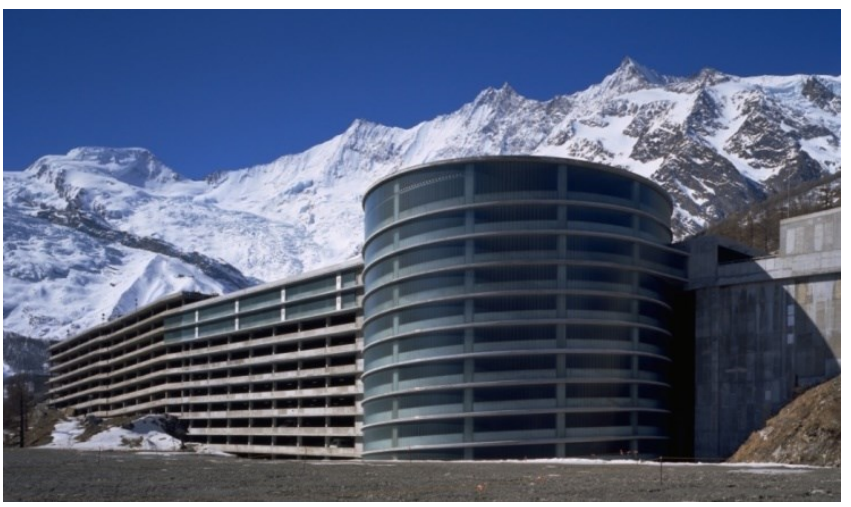

Figure 7. Central parking deck in Saas Fee, Switzerland

The concrete overlay of the decks are impregnated with chlorides ranging from $0,5-3,0$ wt. $\% / w t . \%$ cement near the loose steel reinforcement. The decks are reinforced with unbonded post-tensioned tendons. Conventional techniques would require the removal of with chloride contaminated concrete, coating of the steel reinforcement and refurbishment with repair mortar or concrete. This 
procedure would be highly delicate with regard to the unbonded tendons in the parking deck - damage to these tendons has to be avoided under any circumstances.

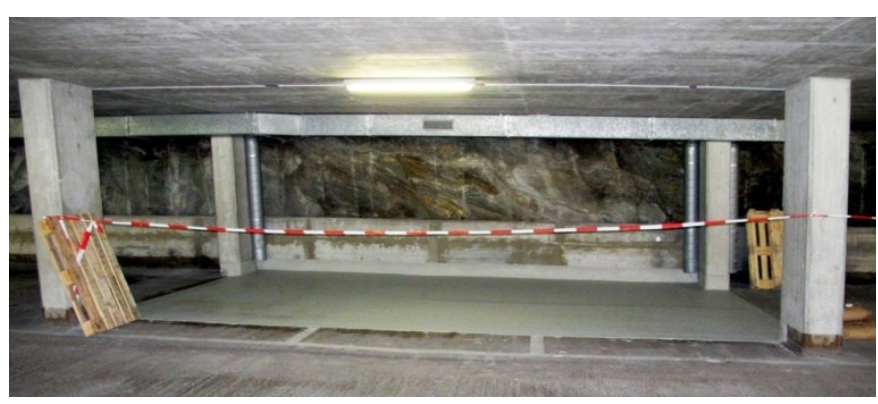

Figure 8. EZA-installation in one parking booth

With regard to the pre-stressed tendons and the risk of $\mathrm{CP}$ induced hydrogen embrittlement, galvanic corrosion protection offers a safe and reliable remediation technique. In July 2011, on a parking booth, the EZA system was installed on $30 \mathrm{~m}^{2}$ concrete surface (figure 8 ).

The EZA system has been coated with a tough elastic, static crack-bridging waterproofing and wearing surface layer of a broadcast total solid epoxy Sikafloor-390, covered by a high abrasion resistant sealcoat of total solid epoxy Sikafloor-354.The EZA is in operation since August 2011, exposed to the harsh alpine conditions $1880 \mathrm{~m}$ above sea level. Data show that it is protecting the steel reinforcement reliably and safely with zero-maintenance expenditures (Figure 9).

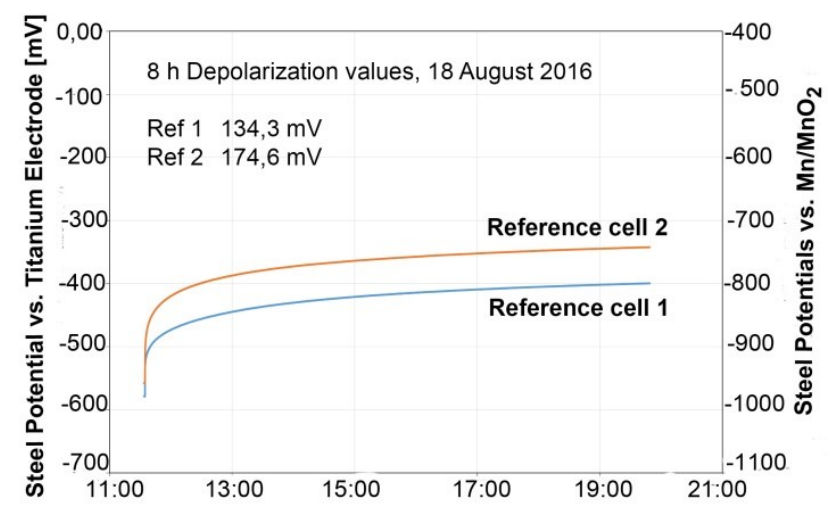

Figure 9: $8 \mathrm{~h}$ depolarisation measurements of the EZA installation in the Saas Fee parking deck performed 18 August 2016 by Suicorr [7]

\section{EZA Installation at an Alpine Tunnel Entrance}

The retaining walls at a tunnel entrance in the Styrian Alps (Obdach, national road B78) are exposed to high thaw salt loads during winter time. The impact of the salt exposure is intensified by the wind-channel effect caused by the tunnel resulting in strong climbing winds emanating from the tunnel (figure 10). The intense weathering resulted in extensive erosion of the protective acrylic coating on the concrete wall and ingress of de-icing salt into the concrete overlay leading to chloride contents ranging from 1,6 wt.\% - 6 wt.\%/wt. cem., resulting in significant corrosion of the reinforcing steel. In some areas, loss of cross section of up to $70 \%$ and disbondement of steel/concrete was observed.
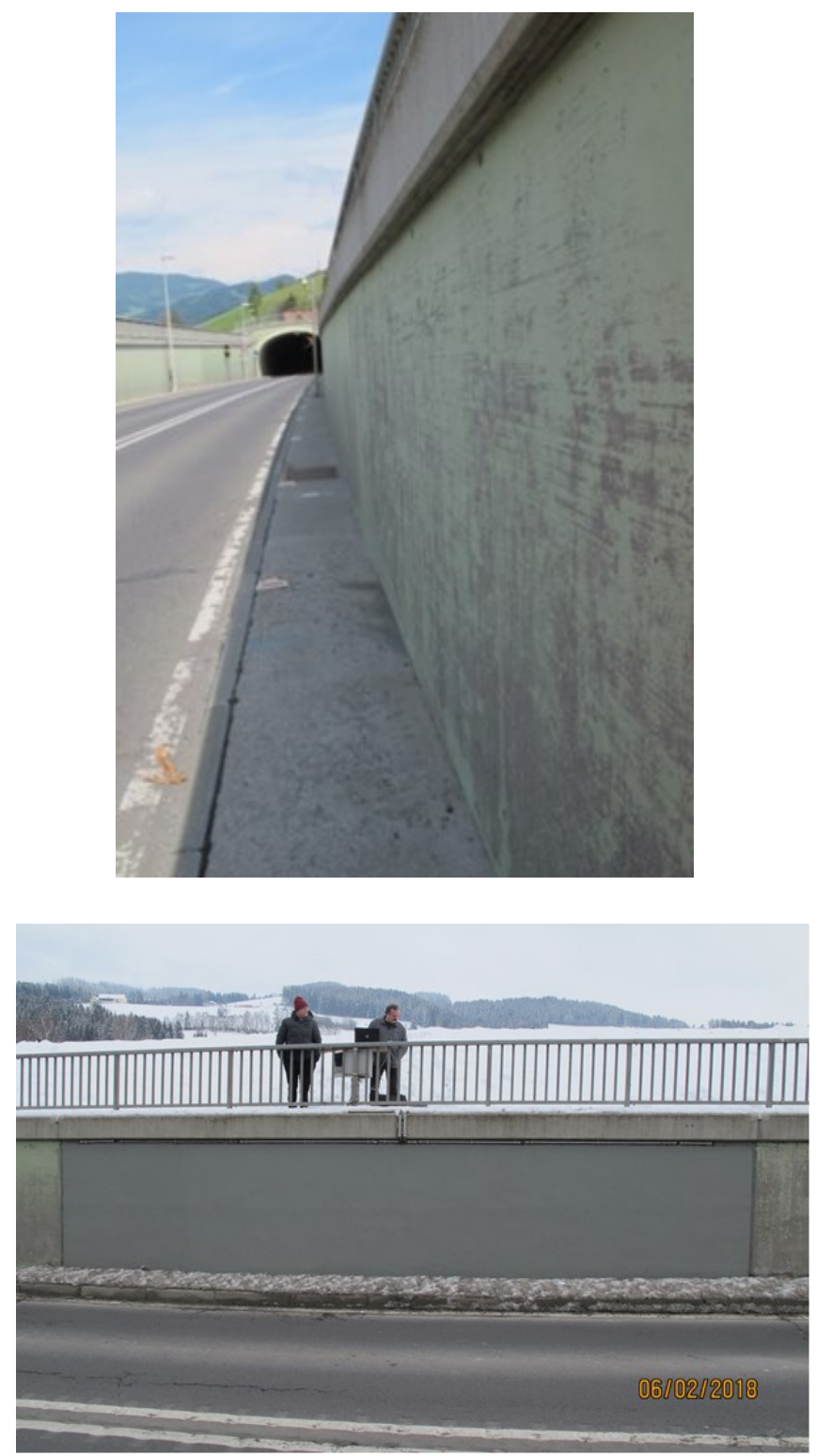

Figure 10. Retaining wall at the tunnel entrance in Obdach, Styria, before (top) and after installation of the SEZAC system (bottom): SEZAC covered with Sikagard-332 TU certified for tunnel applicationjs, topped with Sikagard-260 WPU.

The SEZAC (shrinkage controlled embedding zinc anode cement) galvanic protection system was chosen for evaluation of a maintenance free corrosion protection system that allows reliable corrosion protection without extensive concrete repair works. The SEZAC system was applied in July/August 2018 on an area of $20 \mathrm{~m}^{2}$ in cooperation with iCOR by order of the Styrian Road 
Authority. The SEZAC galvanic anode was covered with an epoxy coating from SIKA certified for tunnel applications- Sikagard-332 TU, topped with Sikagard-260 WPU as a UV protective dirt repellent coating.

Three ERE 20 reference cells and one set of macro-cell sensors [8] were installed to monitor the corrosion protection efficiency. The galvanic current, the steel potentials and the macro-cell currents are monitored and every 4 weeks 24 hour depolarization measurements are performed by the CAS modular data acquisition and control (MODAC) system.

The monitored values (figure 11) and the depolarisation values (table 3) show that the SEZAC protects the steel reinforcement from the start on (2 August 2017) reliable and delivers high galvanic currents also during temperatures near the freezing point during winter time.

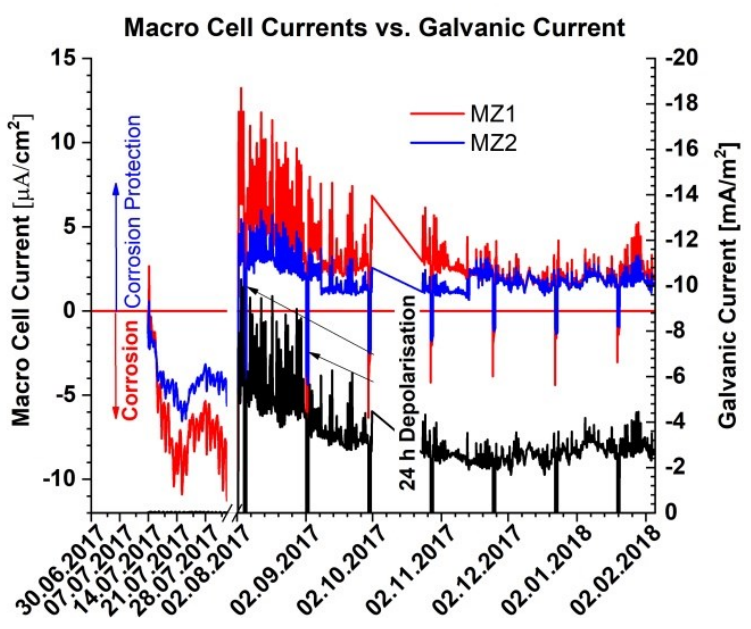

Figure 11. Galvanic Current of the EZA-System in relation to macro-cell currents measured by macro-cell sensors. Data from 14 July 2017 till 6 February 2018 showing influence of galvanic current on macro-cell currents.

Table 3. Verification of the effectiveness of the EZA system by depolarization measurements according to ISO EN 12 696. Potential values in $\mathrm{mV}$

\begin{tabular}{|c|c|c|c|c|c|c|c|}
\hline Date & $\begin{array}{l}\text { Ref. } \\
\text { cell }\end{array}$ & $\begin{array}{l}\text { On } \\
\text { pot. }\end{array}$ & $\begin{array}{l}\text { Inst. } \\
\text { off }\end{array}$ & $\begin{array}{l}4 \mathrm{~h} \\
\text { off }\end{array}$ & $\begin{array}{l}24 \mathrm{~h} \\
\text { off }\end{array}$ & $\begin{array}{l}24 \mathrm{~h} \\
\text { Dep. }\end{array}$ & $\begin{array}{l}\mathrm{T} \\
{ }^{\circ} \mathrm{C} \\
\end{array}$ \\
\hline \multirow{3}{*}{$\begin{array}{c}6 \\
\text { Aug. } \\
2017\end{array}$} & R1 & -615 & -585 & -474 & -456 & 129 & \multirow[t]{3}{*}{27,4} \\
\hline & R2 & -669 & -620 & -482 & -467 & 153 & \\
\hline & R3 & -609 & -577 & -494 & -477 & 100 & \\
\hline \multirow{3}{*}{$\begin{array}{c}21 \\
\text { Jan. } \\
2018\end{array}$} & R1 & -644 & -598 & -467 & -430 & 168 & \multirow[t]{3}{*}{2,6} \\
\hline & R2 & -644 & -613 & -481 & -438 & 175 & \\
\hline & R3 & -709 & -655 & -438 & -475 & 180 & \\
\hline
\end{tabular}

\section{Conclusions}

The performance of the novel EZA galvanic corrosion protection system, consisting of a zinc mesh embedded into a proprietary non-cementitious binder matrix was installed on condrete members of three different civil structures - an alpine road bridge in Austria, a viaduct in The Hague, NL and on the pavement of a parking deck in Saas Fee, $\mathrm{CH}$, evaluated over a period of $7-10$ years by measurements according to ISO EN12696 and with macro cell sensors, show that the EZA system protects the steel reinforcement of the concrete members reliably from corrosion. Frequent wet and dry cycles and prolonged freeze thaw exposure did not affect performance. An optimized galvanic protection system - the SEZAC galvanic anode covered with high end Epoxy/PU coatingapplied on retaining walls exposed to harsh weathering conditions proves to be efficient in protecting the steel reinforcement from corrosion.

We greatly acknoledge and thank for the support by the Styrian Road Authority, especially to Andreas Kammersberger, for making the EZA installation at Alplgraben bridge and at the tunnel entrance in Obdach possible. We furthermore acknowledge and thank for the support by Sika Switzerland and Sika Services for support and providing materials for EZA installation at the parking deck in Saas Fee and Sika Austria for support and providing materials for the EZA installation at the tunnel entrance in Obdach.

\section{References}

1. J.L. Kepler, D. Darwin, J.R. Locke, Evaluation of Corrosion Protection Methods for Reinforced Concrete Highway Structures, Structural Engineering and Engineering Materials SM Report No. 58, University of Kansas Center for Research Inc., Lawrence, Kansas, May 2000

2. Y.P. Virmani, G.G. Clemena, Corrosion Protection Concrete Bridges Report No. FHWA-RD-98-088, Federal Highway Administration, Washington, D.C., (1998)

3. R.J. Kessler, R.G. Powers, I.R. Lasa, Corrosion 2002, paper 02254, NACE International (2002)

4. S. Szabo, I. Bakos, Corrosion Reviews 24, pp. $231-$ 280 (2006)

5. S.J. Bullard, S. Cramer, B. Covino Final Report Effectiveness of Cathodic Protection, SPR 345. Report No. FHWA-OR-RD-09-18, National Energy Technology Laboratory, Oregon, (2009)

6. R. Bäßler, A. Burkert, G. Eichler, J. Mietz, , Proceedings of the Second International Conference on Concrete Repair, St. Malo, France, 27-29 June 2006: 220-234. Garston Watford: BRE Press (2006)

7. D. Oberhänsli, August 2016, www.suicorr.com

8. W. Schwarz, J. Tritthart, Materials and Corrosion, 60, $138-147$ (2009) 
9. W. Schwarz, F. Müllner, A. van den Hondel, Concrete Repair, Rehabilitation and Retrofitting III, Eds. Beushausen M.G., Dehn F., Moyo P., CRC Press, pp 357 - 358 (2012)

10. W. Schwarz, F. Müllner, A. van den Hondel, Grantham, M. Muhammed Basheer ,P.A,. Magee, B., Soutsos, M. (Eds.), Concrete Solutions, CRC Press, London, pp 223 -228, (2014) 